\title{
Quality Economic Growth as an Indicator of Economic Development
}

\author{
Ida Nuraini, Happy Febrina Hariyani* \\ Faculty of Economics and Business, Universitas Muhammadiyah Malang \\ "Corresponding Author: happyfebrina@umm.ac.id
}

Recieved: November 2018 | Revised: January 2019 | Accepted: February 2019

\begin{abstract}
This study aims to map the districts/cities in East Java that is classified as having quality economic growth, as well as formulating a concept of quality economic growth by examining several social and economic indicators such as unemployment, income distribution across regions, income distribution among economic sectors, equity investment, and poverty.

Using Klassen's typology analysis, it is found that most (19 regions) districts and cities in East Java are in the advanced category but depressed. Meanwhile, there are 8 regions that are classified as advanced and growing rapidly and 10 regions are classified as regions that can grow fast and 1 region classified as relatively underdeveloped, namely Tuban District. While the regions that have qualified economic growth are Lamongan District, Jember District, Probolinggo, Madiun, Batu, Blitar, Pasuruan and Mojokerto. Based on the Fix Effect regression model, it can be concluded that the number of industries, education facilities and the contribution of tertiary sector have a positive and significant effect on economic growth. On the other hand, population and the contribution of secondary sector give a negative and significant impact on qualified economic growth.
\end{abstract}

Keywords: quality economic growth, income inequality income, East Java

JEL Classification: $\mathrm{C} 1, \mathrm{C} 3, \mathrm{O} 1, \mathrm{O} 3$

How to Cite: Nuraini, I., \& Hariyani, H. (2019). Qualified Economic Growth as an Indicator of Economic Development. Jurnal Ekonomi Pembangunan: Kajian Masalah Ekonomi dan Pembangunan, 20(1). doi:https://doi.org/10.23917/jep.v20i1.7104

DOI: https://doi.org/10.23917/jep.v20i1.7104

\section{Introduction}

Economic growth is an increase in the production of all people in a country from year to year. High economic growth is the goal of all countries, because high economic growth can be used as an indicator of the success of a country's economic development. However, there is actually more important than just high economic growth, namely income equity, investment equity, wide employment opportunities and low poverty rates. Gini ratio that shows indicators of inequality over the last five years still range from 0.4. This inequality is getting worse if compared to the previous years since year 2000 .
East Java currently has a higher average economic growth compared to national economic growth. East Java's high economic growth cannot be said to be quality because of this high economic growth. Although it is followed by the distribution of income between districts / cities but it has not been followed by equal distribution of income between economic sectors. Research by Nuraini (2017) regarding the map of economic growth between districts and cities in relation to income distribution, it was concluded that most of the districts and cities in East Java are still classified as advanced but depressed (there are 17 districts and cities) which is regions low economic 
growth compared to the average economic growth in East Java but it has been evenly distributed in the level of income. Meanwhile, there are 15 districts / cities in East Java in the typology of the Advanced and Growing Fast Regions which is the regions with high economic growth compared to the average growth of the East Java region and have been evenly distributed in the level of income. 4 districts / Cities in the regional typology that can still growing fast are regions with high economic growth compared to the average economic growth in East Java but the absence of income distribution and 2 districts / cities in the typology of disadvantaged regions are regions with low economic growth and no equity in income.

The lack of success of governments in achieving the indicator of economic development needs to get attention, especially looking for things that can cause low economic growth and lack of income distribution. With the concept of quality economic growth which are high economic growth and followed by the distribution of income between regions and between economic sectors, low poverty, lack of unemployment, high investment and even distribution in various sectors. It is important to map districts / cities in Java East based on the indicators of quality economic growth.

Economic growth is a development of activities in the economy which causes goods and services produced in society to increase. While according to Prasetyo (2008), economic growth is an increase in output or an increase in aggregate national income within a certain period of time monitored due to an increase in aggregative factors. In these two thoughts there is a similarity in that economic growth is focused on the increase in output.

Adam Smith stated that economic growth has two main aspects, namely output growth and population. The aspect of output growth consists of natural resources, human resources, and existing capital stock. In the theory of Adam Smith, it is said that natural resources are the most dominant in economic growth, while the human resources and capital goods stock only play a passive role in economic growth. Meanwhile, according to the Solow theory, factors of production and technology development play a significant role in increasing economic growth. Solow (1962) said that technological progress is the most dominant in economic growth evidenced in his research that economic growth in the United States is 2.75 percent, half of which is contributed to the technology sector by 1.5 percent.

Mlachila, Tapsoba, and Tapsoba (2014) said that economic development cannot be measured only by increasing economic growth but it must be seen from social factors including health and education. The following figure describes the quality of growth index.

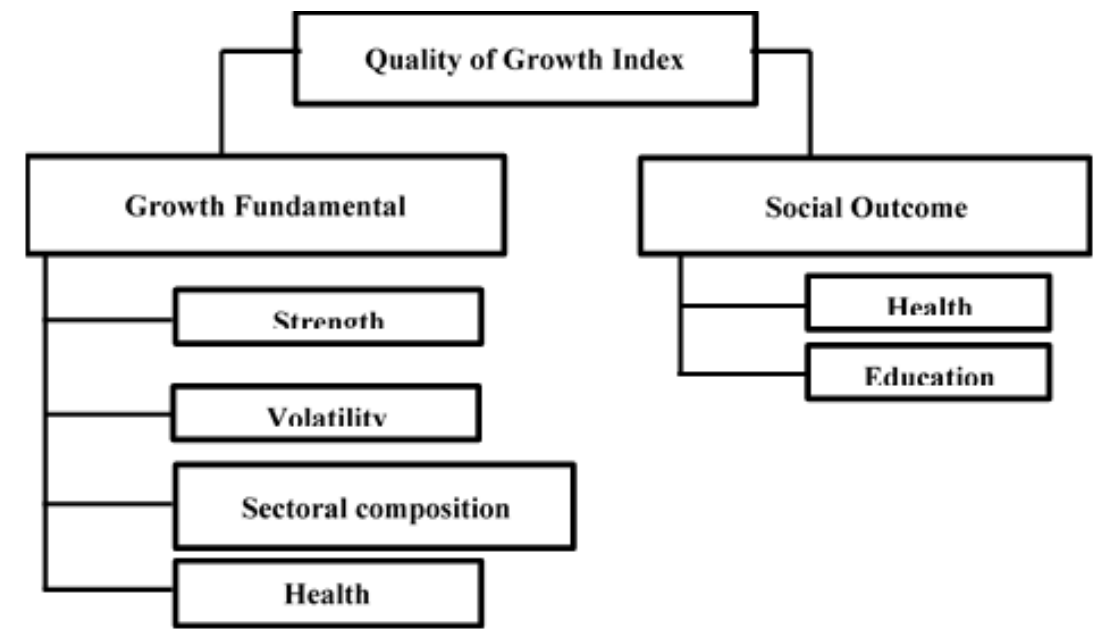

Source: IMF Working Paper No. WP/14/172 
So, the quality of the economy cannot be measured only by increasing economic growth but high unemployment, uneven growth between sectors, uneven income per capita, no social facilities and infrastructure, religion, education, economy and so on. Quality economic growth is quality in all aspects which experience growth and equity.

This research not only aims to find out the factors that influence qualified economic growth, but also tries to map cities and districts in East Java based on quality economic growth indicators. This is expected to give policy makers considerations in determining appropriate regulations in improving the quality of economic growth in cities and districts in East Java.

\section{Research Method}

This study uses two research methods, namely Klassen typology analysis and panel data method. The Klassen typology analysis method was modified from the research conducted by Syafrizal (1997) where in his research he classified regions based on two main indicators, namely economic growth and gross regional income (GDP) per capita regional by determining the average economic growth as vertical axis and average per capita GRDP as the horizontal axis. the regional approach can produce four classifications of districts, each of which has different economic growth characteristics, namely: Rapid Growth Region, Retarded Region, Growing Region, and Relatively Backward Region.

Using the same Klassen Typology as what has been done in previous studies conducted by Raswita and Utama (2009), Sutarno and Kuncoro (2003), Yuliani (2015) in different regions in Indonesia, this research tries to examine the same problem in East Java. Geography Information System (GIS) analysis is used to clarify the results of the IW calculation and the Klassen Typology using the geographical map of the region. Klassen typology is used to map the districts and cities in East Java in the category of quality growth or not

The second method is Panel Data Analysis. It should be noted that the study uses pooled data which combines annual time series data from 2012 to 2016 and 38 cities and districts in East Java as the cross section data. The Panel Data analysis is used to determine the factors that play a role in economic growth. The regression model is as follows:

\section{Gr $=\alpha 1+\beta 1$ IND $+\beta 2$ POP $+\beta 3$ SrnE $+\beta 4$ IPM $+\beta 5$

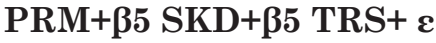

where Gr refers to Economic Growth, IND is the number of industries, POP is Population, SrnE refers to Education Facilities, IPM refers to HDI, PRM is Prymary Sector's Contribution, SKD is Secondary Sector's Contribution, and TRS is Tertiary Sector's Contribution.

\section{Results and Discussions}

Administratively, East Java is divided into 29 districts and 9 cities with the city of Surabaya as the capital of the province. This makes East Java the province that has the most districts / cities in Indonesia. Based on East Java Provincial Regulation Number 16 of 2016, East Java is divided into 5 Regional Coordinating Bodies (Bakorwil). Bakorwil I includes Madiun District, Magetan District, Ngawi District, Ponorogo District, Trenggalek District, Tulungagung District, Pacitan District, Madiun District, and Kediri District. Bakorwil II includes Bojonegoro District, Lamongan District, Tuban District, Jombang District, Mojokerto District, Gresik District, Nganjuk District, and Mojokerto. Bakorwil III covers Malang District, Pasuruan District, Sidoarjo District, Blitar District, Blitar, Batu, Pasuruan and Surabaya. Bakorwil IV covers Pamekasan District, Bangkalan District, Sampang District, and Sumenep District. Bakorwil V covers Jember District, Lumajang District, Bondowoso District, Probolinggo District, Banyuwangi District, and Probolinggo.

Based on the Bakorwil mentioned above, it can be seen that Bakorwil I consists of 10 districts/ cities, Bakorwil II consists of 8 districts /cities, Bakorwil III is 9 districts / cities, Bakorwil IV consists of 4 districts, and Bakorwil $\mathrm{V}$ consists of 7 districts / cities. The total of districts/cities in all 
Bakorwil are 38 districts / cities. Bakorwil itself is formed as having the duties and functions of coordinating guidance, supervision, monitoring, and evaluation of governance, development and co-administration and optimization of District / City Regional Governments (Regional Regulation No. 16 of 2016).

The research object used in this study is 38 districts / cities in East Java consisting of
29 districts and 9 cities which will be divided into 4 categories according to the Klassen typology analysis, namely Advanced and Growing Category, Potential and Developing Category, Advanced but Depressed Category. and Relatively Disadvantaged Category. The results of the Klassen typology analysis is obtained in the following table:

Table 1. Klassen Typology of East Java Province

\begin{tabular}{|c|c|c|}
\hline \multirow{2}{*}{ Sectoral Contribution } & \multicolumn{2}{|c|}{ Sectoral Growth } \\
\hline & $\mathbf{G i}>\mathbf{g}$ & $\mathbf{G i}<\mathbf{g}$ \\
\hline IW $_{\mathrm{i}}<\mathrm{IW}$ & $\begin{array}{l}\text { Batu } \\
\text { Madiun } \\
\text { Probolinggo } \\
\text { Blitar } \\
\text { Pasuruan } \\
\text { Mojokreto } \\
\text { District Lamongan } \\
\text { District Jember } \\
\text { Advanced and Growing Region }\end{array}$ & $\begin{array}{l}\text { District. Pacitan } \\
\text { District. Ponorogo } \\
\text { District. Trenggalek } \\
\text { District. Pamengkasan } \\
\text { District. Jombang } \\
\text { District. Ngawi } \\
\text { District. Madiun } \\
\text { District. Situbondo } \\
\text { District. Magetan } \\
\text { District. Nganjuk } \\
\text { District. Tulung Agung } \\
\text { District. Kediri } \\
\text { District. Blitar } \\
\text { District. Bondowoso } \\
\text { District. Lumajang } \\
\text { District. Probolinggo } \\
\text { District. Sumenep } \\
\text { District. Sampang } \\
\text { District. Bangkalan } \\
\text { Advanced but Depressed Region }\end{array}$ \\
\hline $\mathrm{IW}_{\mathrm{i}}>\mathrm{IW}$ & $\begin{array}{l}\text { District. Bojonegoro } \\
\text { District. Gresik } \\
\text { Surabaya } \\
\text { Malang } \\
\text { Kediri } \\
\text { District. Pasuruan } \\
\text { District. Mojokreto } \\
\text { District. Sidoarjo } \\
\text { District. Banyuwangi } \\
\text { District. Malang } \\
\text { Potential and Developing Region }\end{array}$ & $\begin{array}{l}\text { District. Tuban } \\
\text { Relatively Disadvantaged Region }\end{array}$ \\
\hline
\end{tabular}

Source: Primary data (processed)

Description: IWi $=$ Inequality in District/City region i; IW = Inequality in the average district/city region in East Java Province; $\mathrm{Gi}=$ Economic Growth of District/City region i; G = Economic growth in the average district/city region in East Java Province 


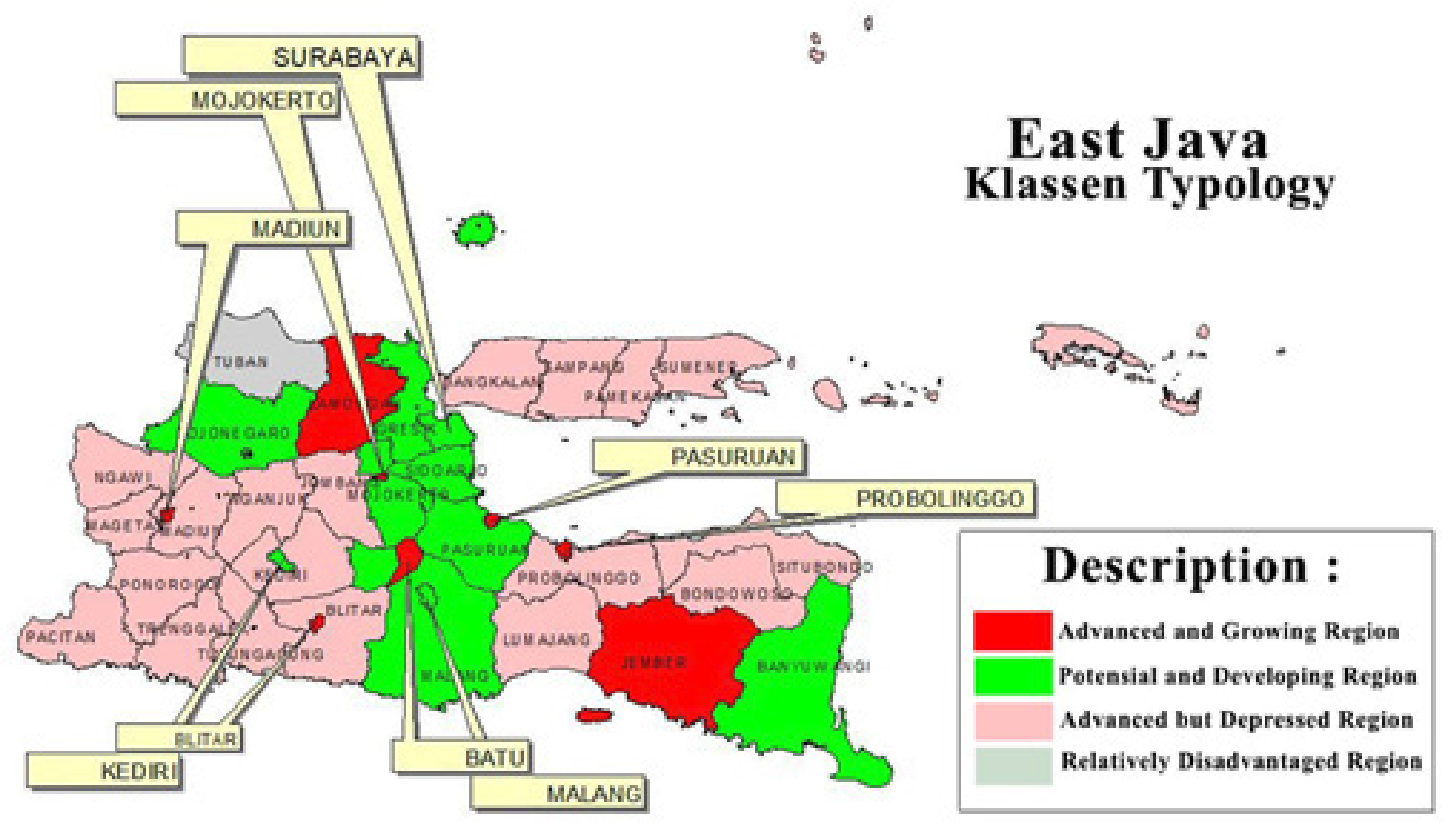

Figure 1. Klassen Typology in East Java

Based on the Geography Information System (GIS) analysis, grouping of the categories can be described in a Klassen typology map of East Java Province as in Figure 1. The grey color illustrates the relatively disadvantage regions, namely regions with low economic growth compared to the average economic growth of the cities/districts in East Java and have a high-income gap compared to the average gap in the districts / cities in East Java. The more regions in the advanced and rapidly growing category, the better the quality of economic growth (Nuraini, 2017).

\subsection{Factors Affecting Qualified Economic Growth}

This section aims to find out the factors that influence qualified economic growth. This is in line with Joseph. E (2001) view that differences in the quality of economic growth in a country are influenced by knowledge factors including production processes and social and organizational capital. In the neo-classical view, a developing or relatively backward country only needs to increase the accumulation of $\mathrm{K}, \mathrm{L}$ and $\mathrm{H}$ and its allocation efficiency. Thomas et al. (2000) stated that development performance includes more than an increase in per capita income. Equity opportunities to obtain education, job opportunities, health services, a healthier environment are the factors that determine growth.

In this data panel analysis, we use the number of industries, population, education facilities, HDI, the contribution of primary, secondary and tertiary sector as independent variables which then estimate to give impacts on economic growth.

The number of industries has a positive and significant effect on economic growth. The interaction between human capital and structural change in high knowledge- intensive industries impacts significantly on economic growth (Teixeira \& Queirós, 2016). The 'high-tech' industries have higher growth rates of productivity and therefore contribute more than proportionally to economic growth (Silva \& Teixeira, 2011). Several studies have been showed that the productive structure of an economy and especially its dynamics, i.e., "structural change" which shifts in sectoral composition where certain industries gain relative shares in economy, emerge as an important determinant of economic growth (Montobbio, 2002; Saviotti \& Frenken, 2008; Silva \& Teixeira, 2011) 
Avalaible online at http://journals.ums.ac.id, Permalink/DOI: 10.23917/jep.v20i1.7104

Jurnal Ekonomi Pembangunan: Kajian Masalah Ekonomi dan Pembangunan, 20 (1), 2019, 80-86

Table 2. The Estimation Results of Factors Affecting Qualified Economic Growth Using Fixed Effect Model

\begin{tabular}{lrrr}
\hline \multirow{2}{*}{\multicolumn{1}{c}{ Independent Variable }} & \multicolumn{3}{c}{$\begin{array}{c}\text { Dependent Variable } \\
\text { Economic Growth (GR) }\end{array}$} \\
\cline { 2 - 4 } & Coefficient & Std. Error & Prob \\
\hline C & 6.301065 & 0.956463 & 0.0000 \\
Number of Industries (IND) & 0.002364 & 0.000506 & $0.0000^{*}$ \\
Population (POP) & $-4.92 \mathrm{E}-07$ & $1.89 \mathrm{E}-07$ & $0.0101^{*}$ \\
Education Facilities (SRNE) & 0.000325 & $7.21 \mathrm{E}-05$ & $0.0000^{*}$ \\
Contribution of Primary Sector (PRM) & $-2.72 \mathrm{E}-05$ & $2.45 \mathrm{E}-05$ & 0.2678 \\
Contribution of Secondary Sector (SKD) & $-1.32 \mathrm{E}-05$ & $5.35 \mathrm{E}-06$ & $0.0144^{*}$ \\
Contribution of Tertiary Sector (TRS) & $1.17 \mathrm{E}-05$ & $5.29 \mathrm{E}-06$ & $0.0283^{*}$ \\
Human Development Index (IPM) & -0.006273 & 0.013026 & 0.6307 \\
R-squared & 0.660826 & \\
Adjusted R-squared & 0.557904 & \\
F-statistic & 6.420668 & \\
Haussman Test Probability & $0.0000^{*}$ & \\
Chow Test Probability & $0.0000^{*}$ & \\
\hline
\end{tabular}

Description: *) significance level at 5 percent

Population has a negative and significant effect on economic growth. National Research Council (1986) stated that population growth may reduce the growth rate of per capita income because it reduces the per capita availability of exhaustible resources.

Education facilities has a positive and significant effect on economic growth. Education has often been viewed as a more important source of human capital accumulation. This is because in a knowledge economy, education plays the crucial role of providing the highly skilled human capital needed for job creation, economic growth, and prosperity of the individual and the society (Pegkas \& Tsamadias, 2014). Hariyani, Priyarsono, and Asmara (2016) stated that the ease of access to education can affect the quality of human capital in a country which will then become an important variable in influencing a country's economic growth.

The contribution of secondary sector has a negative and significant effect on economic growth while the contribution of the tertiary has a positive and significant effect on economic growth.

\section{Conclusions}

Based on the results of the analysis and discussion described above, it can be concluded that economic growth between districts and cities in East Java is still uneven. Meanwhile, income inequality is also still high, as evidenced by the Williamson index. Based on the Klassen typology analysis, the results show that the regions are in the advanced and rapidly growing category or have quality economic growth consisting of 8 districts / cities which are Lamongan, Jember, Probolinggo, Madiun, Batu, Blitar, Pasuruan and Mojokerto. The regions in the Potential and developing category consist of 10 districts / Cities, Advanced Regions but are depressed as many as 19 districts / Cities and Relatively disadvantaged is Lamongan. However, on average, it can be said that the districts / cities in East Java are in the advanced but depressed category so that there are still many districts / cities in East Java that need to be improved economic growth.

Whereas in the panel data regression analysis it can be concluded that the number of industries, education facilities and the contribution of tertiary sector have a positive 
and significant effect on economic growth. On the other hand, population and the contribution of secondary sector give a negative and significant impact on qualified economic growth.

Regional government should put an effort to increase economic growth by reducing income inequality. The increase in the contribution of the primary sector, especially the agricultural sector, which is the base sector in several districts in East Java and the increase in the contribution of the secondary sector, mainly the industrial sector plays an important role in economic growth. Increasing the number of industries must pay attention to employment. Population growth must be pursued accompanied by improvements in quality.

\section{References}

Hariyani, H. F., Priyarsono, S. S., \& Asmara, A. (2016). Jurnal Ekonomi dan Kebijakan Pembangunan, hlm. 32-44 Vol 5 No 2. Jurnal Ekonomi Dan Kebijakan Pembangunan, $5(2), 32-44$.

Joseph. E, S. (2001). Development Thinking at the Millennium. Washington DC.

Mlachila, M., Tapsoba, R., \& Tapsoba, S. J. A. (2014). A Quality of Growth Index for Developing Countries: A Proposal. IMF Working Paper (Vol. WP/14/12).

Montobbio, F. (2002). An evolutionary model of industrial growth and structural change, 13, 387-414.

National Research Council. (1986). Population Growth and Economic Development: Policy Questions. Washington DC. Retrieved from https://www.ssc.wisc.edu/ walker/wp/wpcontent/uploads/2012/09/NRC1986.pdf

Nuraini, I. (2017). Kualitas Pertumbuhan Ekonomi Daerah Kabupaten/Kota di Jawa Timur, 79-93.

Pegkas, P., \& Tsamadias, C. (2014). Does Higher Education Affect Economic Growth? The Case of Greece, (September), 37-41. https:// doi.org/10.1080/10168737.2014.894551
Prasetyo, P. E. (2008). The Quality of Growth: Peran Teknologi dan Investasi Human Capital sebagai Pemacu Pertumbuhan Ekonomi Berkualitas, 1, 1-15.

Putu, N., Eka, M., Utama, M. S., Ekonomi, J., Fakultas, P., Universitas, E., ... Klassen, T. (2009). Analisis pertumbuhan ekonomi dan ketimpangan pendapatan antar kecamatan di kabupaten gianyar, 119-128.

Saviotti, P. P., \& Frenken, K. (2008). Export variety and the economic performance of countries, 201-218. https://doi.org/10.1007/ s00191-007-0081-5

Silva, E. G., \& Teixeira, A. A. C. (2011). Does structure influence growth? A panel data econometric assessment of " relatively less developed " countries , 1979 - 2003, 20(2), 457-510. https://doi.org/10.1093/icc/dtr003

Solow, R. M. (1962). Technical Progress, Capital Formation, and Economic Growth. The American Review, 52(3), 76-86.

Sutarno, S., \& Kuncoro, M. (2003). Pertumbuhan Ekonomi Dan Ketimpangan Antar Kecamatan Di Kabupaten Banyumas, 1993-2000. Economic Journal of Emerging Markets, 8(2).

Syafrizal. (1997, March). Pertumbuhan Ekonomi dan Ketimpangan Regional Wilayah Indonesia Bagian Barat. PRISMA, 27-38.

Teixeira, A. A. C., \& Queirós, A. S. S. (2016). Economic growth, human capital and structural change: A dynamic panel data analysis. Research Policy, (October 2017). https://doi.org/10.1016/j.respol.2016.04.006

Thomas, V., Dailimi, M., Dhareshwar, A., Kaufmann, D., Kishor, N., López, R., \& Wang, Y. (2000). The quality of growth. The World Bank.

Yuliani, T. (2015). Pertumbuhan ekonomi dan ketimpangan pendapatan antar kabupaten di kalimantan timur, 8(1). https://doi. org/10.15294/jejak.v7i1.Journal 